GA-A23494

\title{
THERMAL HYDRAULIC ANALYSIS OF FIRE DIVERTOR
}

\author{
C.B. BAXI, M.A. ULRICKSON, D.E. DRIEMEYER, \\ and P. HEITZENROEDER
}




\section{DISCLAIMER}

This report was prepared as an account of work sponsored by an agency of the United States Government. Neither the United States Government nor any agency thereof, nor any of their employees, makes any warranty, express or implied, or assumes any legal liability or responsibility for the accuracy, completeness, or usefulness of any information, apparatus, product, or process disclosed, or represents that its use would not infringe privately owned rights. Reference herein to any specific commercial product, process, or service by trade name, trademark, manufacturer, or otherwise, does not necessarily constitute or imply its endorsement, recommendation, or favoring by the United States Government or any agency thereof. The views and opinions of authors expressed herein do not necessarily state or reflect those of the United States Government or any agency thereof. 


\title{
THERMAL HYDRAULIC ANALYSIS OF FIRE DIVERTOR
}

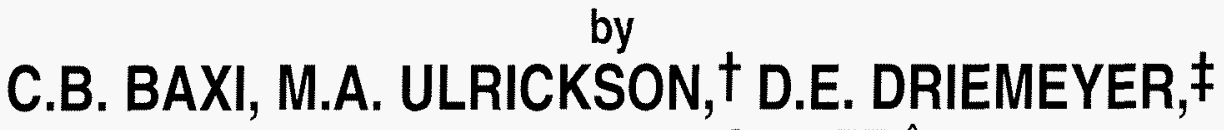 \\ and P. HEITZENROEDER $\diamond$
}

This is a preprint of a paper presented at the 14th Topical Meeting on the Technology of Fusion Energy, October 15-19, 2000 in Park City, Utah and to be published in Fusion Technology.

\author{
†Sandia National Laboratories \\ FBoeing \\ $\checkmark$ Princeton Plasma Physics Laboratory
}

Work supported by

the U.S. Department of Energy under

Contract Nos. DE-ACO3-98ER54411, DE-AC02-76CH03073, and DE-AC04-94AL85000 


\title{
THERMAL HYDRAULIC ANALYSIS OF FIRE DIVERTOR
}

\author{
C.B. Baxi, ${ }^{1}$ M.A. Ulrickson, ${ }^{2}$ D.E. Driemeyer, ${ }^{3}$ and P. Heitzenroeder ${ }^{4}$ \\ ${ }^{1}$ General Atomics, P.O. Box 85608, San Diego, California 92186-5608 \\ ${ }^{2}$ Sandia National Laboratories, P.O. Box 5800, Albuquerque, New Mexico 87185 \\ ${ }^{3}$ Boeing, P.O. Box 516, St. Louis, Missouri 63166-0516 \\ ${ }^{4}$ Princeton Plasma Physics Laboratory, P.O. Box 451, Princeton, New Jersey 08543-0451
}

\begin{abstract}
The Fusion Ignition Research Experiment (FIRE) is being designed as a next step in the U.S. magnetic fusion program. The FIRE tokamak has a major radius of $2 \mathrm{~m}$, a minor radius of $0.525 \mathrm{~m}$, and liquid nitrogen cooled copper coils. The aim is to produce a pulse length of $20 \mathrm{~s}$ with a plasma current of $6.6 \mathrm{MA}$ and with alpha dominated heating.
\end{abstract}

The outer divertor and baffle of FIRE are water cooled. The worst thermal condition for the outer divertor and baffle is the baseline D-T operating mode (10 T, 6.6 MA, $20 \mathrm{~s}$ ) with a plasma exhaust power of $67 \mathrm{MW}$ and a peak heat flux of $20 \mathrm{MW} / \mathrm{m}^{2}$. A swirl tape (ST) heat transfer enhancement method is used in the outer divertor cooling channels to increase the heat transfer coefficient and the critical heat flux (CHF). The plasma-facing surface consists of tungsten brush.

The finite element (FE) analysis shows that for an inlet water temperature of $30^{\circ} \mathrm{C}$, inlet pressure of $1.5 \mathrm{MPa}$ and a flow velocity of $10 \mathrm{~m} / \mathrm{s}$, the incident critical heat flux is greater than $30 \mathrm{MW} / \mathrm{m}^{2}$. The peak copper temperature is $490^{\circ} \mathrm{C}$, peak tungsten temperature is $1560^{\circ} \mathrm{C}$, and the pressure drop is less than $0.5 \mathrm{MPa}$. All these results fulfill the design requirements.

\section{INTRODUCTION}

The Fusion Ignition Research Experiment (FIRE) is being designed for high power density and advanced physics operating modes. ${ }^{1}$ The FIRE has a double-null divertor configuration. The baffle and outer divertor are actively water cooled. The inner divertor has low heat flux and is cooled by conduction to the copper shell inside the vessel wall. Figure 1 shows the cross section of the FIRE with location of inner and outer divertor and baffle.

\section{DIVERTOR AND BAFFLE GEOMETRY}

The divertor and baffle design of the FIRE is based on technologies developed for ITER. ${ }^{2}$ There are 32 modules each of the divertor and baffle (16 upper and 16 lower). A module is divided into 24 copper $(\mathrm{Cu}-\mathrm{Cr}-\mathrm{Zr}$ ) plates across the front surface. The copper plates include tungsten-brush armor as a plasma-facing component (PFC) and coolant channels on both divertor and baffle. The tungsten rods are $3 \mathrm{~mm}$ in diameter arranged on a triangular pitch of $3.1 \mathrm{~mm}$. The rods of the brush have a conical tip over $1 \mathrm{~mm}$ length on the heat sink side. The tungsten rods are joined to the copper with HIP-bonding process. $^{2}$ A $5 \mathrm{~mm}$ thickness of the PFC gives adequate lifetime under the expected disruption conditions. The use of tungsten brush reduces the stresses in the PFC. This is

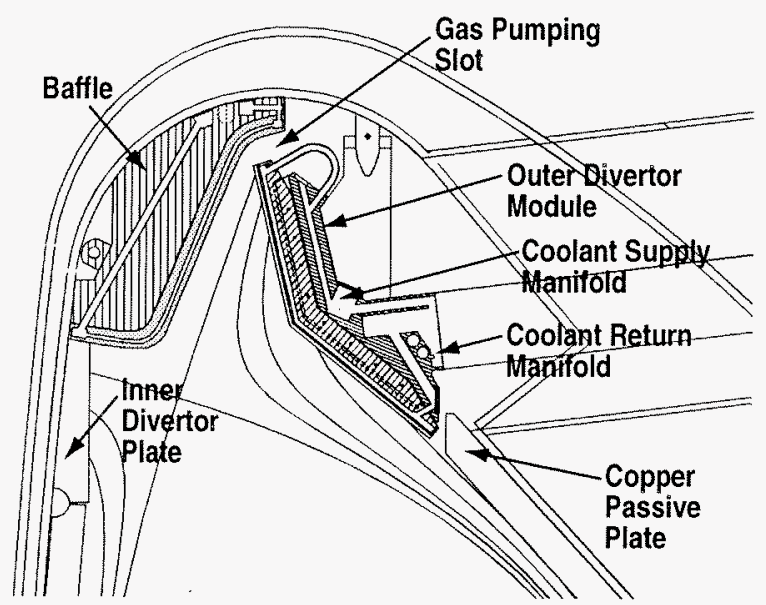

Fig. 1. Cross Section Through FIRE divertor and baffle. 
one of the designs for the ITER divertor PFC in the highest heat flux region. This PFC has been successfully fabricated and tested for ITER and found suitable for heat fluxes upto $25 \mathrm{MW} / \mathrm{m}^{2}{ }^{2}$. The divertor module is $0.67 \mathrm{~m}$ in the toroidal direction and $0.55 \mathrm{~m}$ in the poloidal direction and baffle module is 0.63 in toroidal and 0.50 in poloidal direction. The flow direction is chosen to be poloidal so that the power input to each flow channel is equal. ${ }^{3}$ The divertor has a total of $48,8 \mathrm{~mm}$ ID cooling channels for each module. The baffle has 24 cooling channels of $10 \mathrm{~mm}$ diameter.

\section{POWER FLOWS}

The FIRE tokamak is planned to be operated in four modes: 1) base line D-T (20s), 2) an advanced physics D-D (215 s), 3) a long burn D-T mode (31 s), and 4) a high field operation D-T (12 T, $8 \mathrm{MA}, 12 \mathrm{~s})$. The heat loads on the outer divertor and baffle are highest during the base line D-T operation with power flows as shown in Table I.

Table I. The power flows during baseline D-T mode

\begin{tabular}{lcc}
\hline & Outer Divertor & Baffle \\
\hline Total Power $(\mathrm{MW})$ & 34.3 & 10.7 \\
Peak Power/module & 2.32 & 0.58 \\
$(\mathrm{MW})$ & & \\
Peak Heat Flux & 20.0 & 6.00 \\
$\quad\left(\mathrm{MW} / \mathrm{m}^{2}\right)$ & & 34 \\
$\begin{array}{c}\text { Nuclear heating in } \\
\text { Tungsten }\left(\mathrm{W} / \mathrm{cm}^{3}\right)\end{array}$ & 42 & \\
$\begin{array}{c}\text { Nuclear heating in } \\
\text { Cu }\left(\mathrm{W} / \mathrm{cm}^{3}\right)\end{array}$ & 16 & 13 \\
\hline
\end{tabular}

\section{THERMAL HYDRAULIC ANALYSIS}

The thermal design criteria for divertor and baffle are:

\author{
Water Inlet Temperature $=30^{\circ} \mathrm{C}$ \\ Heat Loads $=$ as shown in Table $I$. \\ Maximum Tungsten Temperature $=1800^{\circ} \mathrm{C}$ \\ Maximum Copper Temperature $=500^{\circ} \mathrm{C}$ \\ Minimize inlet pressure, flow rate and pumping \\ power \\ Safety Margin on $\mathrm{CHF}=1.5$
}

In order to remove an incident heat flux of $20 \mathrm{MW} / \mathrm{m}^{2}$, a very large flow velocity $(>20 \mathrm{~m} / \mathrm{s})$ is required if smooth channels are used. The flow velocity and flow rate required to cool the outer divertor can be reduced by using a heat transfer enhancement in the flow channels. A review of enhancement methods ${ }^{3}$ shows that a swirl tube (ST) is the best available method. The ST is easy to fabricate and has a large reliable database. For a
ST with a tape thickness of $1.5 \mathrm{~mm}$ and a twist ratio of 2 in the divertor channels of $8 \mathrm{~mm}$ diameter, a flow velocity of $10 \mathrm{~m} / \mathrm{s}$ gives sufficient safety margin on CHF for the divertor. If two adjacent channels are connected in series, the maximum outlet temperature is $95^{\circ} \mathrm{C}$ and minimum exit pressure is $1.05 \mathrm{MPa}$, resulting in a minimum subcooling of $87^{\circ} \mathrm{C}$.

A two dimensional FE analysis of a divertor cell was performed for these flow conditions. The divertor cell consists of a copper mono block $14 \mathrm{~mm} \times 15 \mathrm{~mm}$ with the $5 \mathrm{~mm}$ tungsten brush as PFC. One mm long conical tip of the tungsten rods is embedded in the copper heat sink by high isostatic pressure (HIP) process. An effective thermal conductance of the tungsten copper interphase was determined by a 3-D finite element analysis with COSMOS code. ${ }^{4}$ Figure 2 shows the result. The heat transfer coefficient in the coolant channel is calculated as a function of wall temperature over forced convection, nucleate boiling and post CHF region by the method described in Ref. 3. The pressure drop is calculated by Lopina-Bergles correlation. 5

Figure 3 shows the temperature distribution at the end of $20 \mathrm{~s}$ for the divertor subjected to an incident heat flux of $20 \mathrm{MW} / \mathrm{m}^{2}$ and nuclear heating as shown in Table I. The peak surface temperature is $1585^{\circ} \mathrm{C}$ and the maximum copper temperature is $488^{\circ} \mathrm{C}$. Based on the flow velocity of $10 \mathrm{~m} / \mathrm{s}$, the flow per module is $9 \ell / \mathrm{s}$. Figure 4 shows the transient of the peak surface temperature. A steady state is reached in $6 \mathrm{~s}$. The peak temperatures will be lower by 25 to $50^{\circ} \mathrm{C}$ when axial distribution of heat flux is available and is modeled in the $3 \mathrm{D}$ thermal analysis. Similar analysis was performed for the baffle. Due to lower peak heat flux of $6 \mathrm{MW} / \mathrm{m}^{2}$, smooth channels can be used in this region. Use of heat transfer enhancement is not justified in the baffle region. The

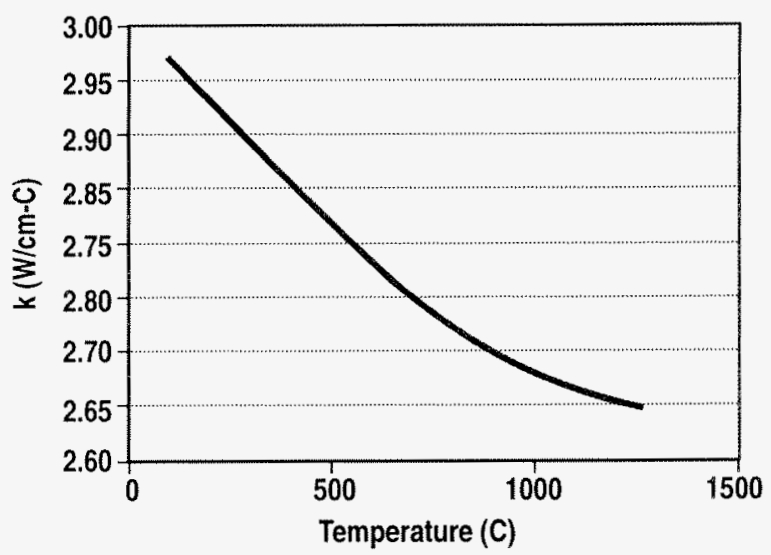

Fig. 2. Effective thermal conductivity of tungsten copper interphase. 